\title{
Research on the Ecological Transformation of College English Course in Computer Network Environment
}

\author{
Zhike $\mathrm{Yu}^{1, \mathrm{a}}$ \\ ${ }^{1}$ Jiangxi Science \&Technology Normal University, Jiangxi, Nanchang, 330013 \\ aemail,
}

Keywords: Computer Network Environment; Ecological; College English Course

\begin{abstract}
In the modern colleges and universities, in order to be able to adapt to the future needs of college students in English, enrich the English teaching situation of college students, in the traditional English teaching model innovation, the use of modern computer network technology advantages into the college English course teaching. And this needs to lead to the original college English teaching ecological imbalance of the reasons for analysis, on this basis, the application of computer network technology to improve the teaching of college English curriculum ecology. Based on the analysis of the causes of ecological imbalance in the original college English teaching, this paper gives the corresponding improvement strategies based on these reasons, aiming at the rational development of the curriculum ecology of benign and sustainable development through rational development of the active consciousness of using ecological factors to the major institutions of our English teaching to go.
\end{abstract}

\section{Introduction}

With the past few years, China has achieved global economic integration, the development of information globalization, Internet technology has been rapid development. In the present society, the Internet technology has been filled with all aspects of people's daily lives, people's way of life and way of thinking has been subtle with the development of the Internet, and language as a normal life activities of the media must also be an unprecedented challenge , But also a great opportunity.

At present, in the English teaching class of our country's major colleges and universities, because of the correlation of many factors or the openness in the teaching process, the connection between the teachers, students and the environment and the interaction between the three which led to the imbalance of classroom ecology. Therefore, through the analysis of the current computer network technology environment, college English curriculum ecological transformation will improve the quality of college English culture and comprehensive ability has an important role.

\section{The Concept of Curriculum Ecology}

With the continuous development of society, people for the "ecological" the definition of the word has not only confined to the field of biology, it has been given a new definition, gradually transformed into a descriptive language. The ecological education is the ecology principle and method in the education of the infiltration and application of the product, it can effectively educate and the surrounding environment interrelated. And as early as the seventies of last century, the famous American designer Ke Lei Ming in the "public education" in the book has been on the concept of educational ecology and thinking patterns were described. At the same time, the American linguistic research expert Hogan in his book "language ecology" which, according to the study of educational phenomena by Klein's use of ecological thinking mode, the education field constitutes a systematic, dynamic System, and emphasizes the relationship between language and the environment, and put forward the language due to the surrounding environment and ecological point of view. The purpose of "language ecology" is to guide people in the process of language learning, we should establish the correct ecological concept, from the ecological perspective of thinking about language problems.

English as the world's most widely used language, in the current major institutions of English 
teaching, in order to be able to effectively improve the efficiency of students learning English and the overall quality of students, it should be based on the current world cultural environment, From the ecological point of view, to achieve the modern English classroom teaching ecology.

In order to be able to construct a good English language environment, the students can effectively improve their language learning ability in the English classroom teaching of the major colleges and universities in China according to the view that the language proposed by Kreeming is ecological and ecological , It must be in the English teaching model which students as the main body, teachers as the auxiliary body, and according to their own teaching content, will be transformed into teaching ecological elements, into the teaching of ecological system which makes teachers and students to establish a Effective link to build a new English classroom teaching model.

\section{The Reasons for the Imbalance of College English Teaching Ecology}

"Flower Pot Effect" Phenomenon. In the traditional English teaching, teachers pay too much attention to the word grammar and other books to explain the knowledge, but ignored the comprehensive use of student language training. This led to the students in the loss of teacher guidance help and it is difficult to normal English learning process. Students can understand the spoken language, but also can see the knowledge of the books on the East, but it cannot effectively carry out the systematic planning of these knowledge cannot be used flexibly in English grammar, effectively organize their own language, more often through the similar sentence of the mechanically applied, resulting in the students to learn the creative ability [1]. And the school's examination-oriented education model also exacerbated the phenomenon of the pots of the phenomenon of serious.

The Closed Type of Traditional English Teaching. Language, is one of the basic tools of communication between people, is the most important means of transmission. Therefore, in the process of learning English should be an open interactive communication activities. Through this exchange, to promote the two sides can effectively enhance their ability. However, in the current college English teaching in our country, due to the influence of traditional ideas, college students are not too exposed to their own problems before exposure, which also led to students rarely use English knowledge and external communication, more often through the classroom time to ask questions to the teacher, and the teacher because of the limited time and other objective factors, in many cases often choose to put the whole question, the consequences of this indoctrination education is often students only English, but not in English.

The Traditional English Teaching Evaluation Is Too Single. In the traditional English teaching, the student's learning evaluation is basically developed by the teacher single-handedly, and the teacher's teaching evaluation is basically the students do, the evaluation system is too simple, and in the evaluation method, the traditional English classroom teaching method only refers to the energy in the teaching of the factors, but ignored in the non-quantifiable also exist in the important factors. And in the current college examinations education, the level of students' skills, the number of knowledge to become a student in the school evaluation of the only standard of good or bad seriously restrict the students during the various aspects of school development.

\section{The Ecological Transformation Strategy of the College English Curriculum under the Computer Network Environment}

Establish the Correct Teaching Philosophy. Under the background of the developed social network technology, the ecologicalization of college English teaching should aim at sustainable development, that is, the requirements of college students' English classroom must comply with and practice the requirements of "College English Teaching Requirements". According to the actual needs of the community, to develop students in the school during the comprehensive application of English ability to enable them in the future social communication which can be fluent in English communication, but also can effectively enhance the cultural quality of students [2].

Develop College English Teaching Environment. According to the requirements of university 
English teaching in our country, the main goal is to construct students 'English cultural thinking and cultivate students' English awareness, so as to improve the students 'ability of learning English and the comprehensive utilization ability of English to promote students' development in the future Which adapt to the needs of social positions, increase the competitiveness of students at the same time, to enhance the overall quality of students. Therefore, teachers should be based on the students' learning situation and social situation, the corresponding adjustment of teaching courses and teaching objectives, and to ensure that the English teaching objectives and English comprehensive quality training objectives consistent, so that teachers in the process of ecological teaching more directional give full play to the effect of English teaching environment. And the most important thing is to pay attention to the interaction between teachers and students to the students as the main body of the classroom, by using the contents of the textbook computer network technology reorganization, the use of network technology interaction and diversity, combined into multimedia courseware content to stimulate students' initiative at the same time to strengthen the students' ability to use English, cultivate students' interest in learning. However, it should be noted that the computer network technology under the college English curriculum ecology, can effectively use the network's rich resources, broaden the horizons of students to improve the efficiency of learning English, but it should be noted that in the computer network technology environment for the transformation of the ecological process of English course, the appropriate use of these computing network tools to avoid the large number of students use the network resources, resulting in too many courseware content, so that students will be more attention to computer applications, affect the students' learning effect, and rely too much on the network tools, the same will lead to the enthusiasm of students to learn to attack, neglect and communication with the teacher, in a passive learning state, undermine the imbalance in college English teaching ecology [3].

The Diversity of the Evaluation System. In the construction of the teaching evaluation system, we should try to let the school, society, family and other more involved in the main body, is conducive to the system from a multi-angle to ensure the integrity of the system, fairness and fairness. At the same time, in order to avoid the unity of evaluation methods, adhere to the quantitative rating and qualitative evaluation of each other in the evaluation of the content should also be a comprehensive and healthy development of students as the goal, so as to promote students' emotions, attitudes, wills, values.

\section{Conclusion}

With the continuous development of computing network technology, more and more technology has been introduced into the classroom teaching, and achieved good results. In the college English teaching, the network has its advantages, also led to college English teaching ecology imbalance. To perfect the integration of traditional English teaching and the advantages of computer network technology, we must be based on contemporary social background, constantly adjust the modern English teaching model, so that it can be accepted by social development from the new establishment of ecological balance of teaching to improve student learning efficiency and the quality of English teaching in colleges and universities.

\section{References}

[1] Dong Dongmou. Computer network environment under the construction of college English ecological teaching model[J]. Henan Agriculture, 2016, 03: 16-17.

[2] Wang Ke Ke. Construction of network environment under the university English ecological curriculum system to explore[J]. Examination and evaluation (College English teaching and research version), 2016, 02: 74-76

[3] Xiu Tingting. Network environment under the university English curriculum ecological teaching balance analysis[J]. Vocational and Technical, 2015, 06: 29-30 